\title{
Silent Conflicts - Human-wildlife interactions in urban spaces
}

\author{
Dr. Gurudas Nulkar
}

Dr. Gurudas Nulkar is a professor at Symbiosis Center for Management, Pune. He is also a trustee of the Ecological Society, Pune. His research interests include industrial sustainability, environmental economics and socio-economic studies. He has published research papers in international journals, authored book chapters and written articles for magazines and newspapers.

\begin{abstract}
This is a conceptual paper which analyses incidents of human-wildlife conflicts occurring in urban spaces. To assist in the choice of mitigation measures, the author proposes a categorization for the urban conflicts. The discussions and categorization are based on study of research papers, media reports, discussions with citizen and wildlife experts and the author's own observations during the last 20 years of living in Pune city.

The author proposes two categories of human-wildlife conflict. The first are 'violent conflicts' which are intended to prevent or remedy an animal intrusion. Such conflicts occur with animals such as leopards, snakes and monkeys which intrude into urban spaces. Violent conflicts are reported by media and studied by the research communities. The other category proposed is 'silent conflicts'. These are conflicts arising inadvertently out of human actions, and with no intention to harm animals. Such conflicts go unnoticed and often happen due to ignorance of the possible aftermath.

The author proposes different mitigation approaches to each of the categories, including the skills required in their implementation.

Keywords : Sahyadri, Northern Western Ghats, Rocky plateaus, Windmills, Windfarm impacts, Area mapping, Ecological management plan
\end{abstract}

\section{Acknowledgements}

The author wishes to express his gratitude to all those who lent their valuable time. Of special mention are - Dharmaraj Patil and Dr. Swati Gole for inputs and reviewing the article, Prof. S.D.Mahajan, Dr. Sanjeev Nalavde, Madhuri Kanetkar, Dr. Kalpana Gupte, Shaishavi Kadekar, Manisha Pathak and Vishakha Rao for sending in cases. Prachi Pande's help in compilation of the cases was most useful.

\section{Introduction}

In a tropical country like India, wildlife were the earliest inhabitants of areas, which are now our cities. However, a burgeoning human population and inevitable habitat modifications that followed, have displaced many of the original inhabitants. The few species that adapted to the human intrusion, continue to reside in urban parks, nooks and gardens, but the others have long moved away. Many of the original inhabitants are replaced by the common generalist species due to which the urban agglomerations have lost faunal uniqueness which still exists in some rural areas. India has 20 cities with over 2 million inhabitants. Over 31\% Indians live in urban areas (Ministry of Home Affairs, 2011) and the growth continues. In the world, by 2025, about 136 new cities are expected to enter the top 600, all of them in the developing world (McKinsey, 2011). The urge to urbanize India has its roots in the Seventh five-year plan, which made a passing mention of the need for urban agglomeration. The Eleventh five-year plan considered urbanization as the '..locus and engine of economic growth' (Planning Commission, 2007) and made it a planning agenda. However, even before independence, rural population has been drawn to India's cities, because of the economic opportunities available. The level of urbanization in India increased from $17.6 \%$ in 1951 to $23.7 \%$ in 1981 and $27.8 \%$ in 2001 (Mohan and Dasgupta, 2004) and the expanse of Indian cities continues to grow. Urban sprawls have replaced mangroves (Valiela, Bowen, and York, 2001), pristine 
forests (Seto, Güneralp, and Hutyra, 2012), flattened hills and diverted rivers (Grimm, et al., 2008). All over the world, urbanization has placed severe stress on the fauna (McKinney, 2008) and in many cases driven them out (Rudel, et al., 2005). If the world population follows the current trajectory, urban land cover is expected to increase by 1.2 million $\mathrm{km} \mathrm{2030,} \mathrm{which} \mathrm{is}$ nearly three times that of circa 2000 (Seto, Güneralp, and Hutyra, 2012). The growth of cities would intensify human-wildlife conflicts (human-wildlife conflict) resulting in extensive destruction of habitats and loss of biodiversity.

Even as the urban biodiversity diminishes, much of human-wildlife conflict studies focus on forest, rural and peri-urban areas, while conflicts in urban spaces are less studied. In India, leopard and monkey intrusions in cities are common incidences and a significant body of research is available on them. However, hardly any studies are available on many other species which are in human conflict in urban spaces. One interesting study on retreating wildlife in Pune enumerates the species distribution in the city and discusses the reasons of conflicts. The paper makes a comparison of Pune and Bangalore urban areas (Nalavde, 2006) and provided useful data for this article.

This article focusses on urban human-wildlife conflicts and proposes a classification of urban humanwildlife conflict into two distinct categories. These are discussed with specific cases of from Pune, Mumbai and Nagpur. Feral species are not covered and the more numerous conflicts on farmlands are not in scope of this article. The discussions which follow are based on the author's personal experiences, reviews of published and unpublished literature, news in various media and discussions with citizens.

\section{Importance of urban biodiversity}

Urban wildlife is a valuable resource. Increasingly, architects and landscape planners are putting efforts to conserve non-human life within urban spaces. The importance of urban biodiversity has been well discussed in literature. Urban biodiversity contributes to the enjoyment of nature (NWRC, 2010) and can be an indicator of ecosystem health (Saldiva and Bohm, 1998) (D.J. Rapport, 1998). It has recreational, aesthetic and spiritual values which are not easy to quantify but add to the uniqueness of the city (Grimm, et al., 2008). For example, the congregation of various water birds near the Bund Garden bridge in Pune city, was a unique feature. This area was identified by Prakash Gole to be protected and subsequently declared as the
Mula-Mutha bird sanctuary, probably one of first such urban space for fauna (Brahme, 2002). The sanctuary was a unique feature of the city while offering recreational opportunities to its citizen. Similarly, the Sanjay Gandhi National Park at Borivali in Mumbai lends a uniqueness to the city.

Even as the benefits of a rich urban biodiversity are well known, of even greater importance is the 'intrinsic value' of wildlife (Boyle and Bishop, 1987), which is the inherent worth of wildlife as an end in itself (Callicott, 2003). In the process of development, this is often overlooked. Many cities were originally established in riparian areas, ecological transition zones, or on land reclaimed from mangrove forests (Kuhn, 2004) (Dearborn and Kark, 2009). These areas contributed to ecosystem services and provided habitat and food to non-human beings. The historical records of Mumbai show that in 1670 several islands were reclaimed by the British government by deforesting mangroves. The islands were joined into one continuous landmass (SPG Marine Ecology Centre, 2006). The mangrove destruction has resulted in a significant reduction in the photosynthetic capacity of the region and displaced many species which breed and live in mangrove swamps. The Indian Constitution acknowledges the intrinsic value of all forms of life. Article $48 \mathrm{~A}$ of the Indian Constitution places responsibility on the state to "...protect and improve the environment and safeguard forests and wildlife of the country." 51A states "...it shall be the duty of every citizen of India to protect and improve the natural environment ... and to have compassion for living creatures." This article was cited by the Supreme Court in the case of displacement of Gir lions, where the Court specifically mentioned that the "...every species has the right to live..." and that "...our approach should be eco-centric and not anthropocentric..." (Necessity of a second home for the Asiatic Lion, 1995). The Court goes on to define the terms ecocentric and anthropocentric and further clarifies all doubts with the statement "...in other words, human interest does not take automatic precedence and humans have obligations to non-human beings independently of human interest." A similar ruling was passed later in 2005 in the case of the Asiatic wild buffalo.

The dazzle of urbanization and the pursuit of anthropogenic activities seems to have made mankind less sensitive to non-human beings, the original inhabitants of cities. While there are very few studies on the magnitude of urban human-wildlife conflicts, as the population and man-made infrastructure increases, so does the conflict. Not all are reported by the media, only the ones which are potentially detrimental to 
humans make it to press. The ones which go unnoticed may probably be do more harm to the environment and to the sustainability of future generations of mankind.

\section{Two types of human-wildlife conflict}

The World Wide Fund for Nature (WWF) defines human-wildlife conflict as "any interaction between humans and wildlife that results in negative impacts on human social, economic or cultural life, on the conservation of wildlife populations, or on the environment" (WWF, 2005). Farmers are perhaps the heaviest sufferers from wildlife damage to crops and have been in conflict with them probably since the arrival of agriculture. But, other than these intrusions, rural residents are generally more tolerant to wild animals (Messmer, 2009) than city dwellers, who often overlook their existence (Lowry, Lill, and Wong, 2012). Considered as the economic engines of a nation's GDP, cities draw huge investments in infrastructure, which are intended to support this role. Cities have altered natural ecosystems to achieve specific economic ends. Something which obstructs this activity, is not welcome as is apparent in the humanwildlife conflicts which take place in urban spaces. In India, the development of urban infrastructure, did not set a clear prioritization for the conservation of species in their habitats. This has resulted in humanwildlife conflicts, some of which go unnoticed. The onslaught of economic growth has resulted in increased conflicts, and as they continue to rise, its effects on ecosystems services and food chains will soon show up. It is then imperative that there are mitigation measures in place to improve the situation. However, the variety of urban conflicts being encoun- tered may require different approaches to alleviate the harm to animals. Towards this end, the author proposes a categorization of urban human-wildlife conflicts, which would need separate approaches to mitigation. The first category is termed as 'silent conflicts'. These conflicts arise from the usual economic activities of man and are characterized by two factors :

i. Inadvertent harm to animals : Human actions are done in their own interest, and there is no intention to harm any species.

ii. Unnoticed result of human actions : The result of these actions, on the animals, is not noticed by the proponent.

The second category are the 'violent conflicts'. In this type of conflict, there is :

i. Intended harm : Human actions are directed towards an animal, to reduce a risk or threat posed by them.

ii. Desired outcome: The outcome of these actions on the animal are intended and noticeable.

Here, human actions are directed towards removal, reduction or killing the animals. Incidences of leopard and monkey intrusions are 'violent' conflicts.

The article discusses both the types of conflicts with examples. A representative list of these conflicts is shown in Table 1.

\section{Silent conflicts in urban areas}

The diminishing population of honey bees in Indian cities is a striking example of a silent humanwildlife conflict. About twenty years ago, an old growth tree in the botanical garden of Fergusson

Table 1 : Categorization of Urban Conflicts

\begin{tabular}{|l|l|l|}
\hline & Human actions leading to conflicts & Representative list of affected species \\
\hline Silent conflicts & $\begin{array}{l}\text { Covering soil with tar/cement, building } \\
\text { walls to water bodies, removal of old } \\
\text { unused buildings, increase in vehicular } \\
\text { traffic, mobile phone towers, electric cables } \\
\text { plantations of exotic trees, air and water } \\
\text { pollution, deformation of hills, firecrackers, } \\
\text { festival and victory celebrations }\end{array}$ & $\begin{array}{l}\text { Honey bees, bats, mongoose, black naped hare, } \\
\text { house sparrows, larks, pipits, chats, swifts, } \\
\text { harriers, baya weavers, barn owls, spotted } \\
\text { owlets, falcons, quails, francolins, Indian eagle } \\
\text { owl, bar headed geese and other migratory } \\
\text { birds, variety of fishes, amphibians and } \\
\text { insects. }\end{array}$ \\
\hline Violent conflicts \\
$\begin{array}{l}\text { Fencing, killing, driving away, poaching, } \\
\text { use of pesticides, traps and baits, scaring }\end{array}$ & $\begin{array}{l}\text { Leopards, snakes, monkeys, civets, honey bees, } \\
\text { bats, pigs, porcupine. } \\
\text { Besides several house and garden pests. }\end{array}$ \\
\hline
\end{tabular}


College, Pune, used to host over 25 bee hives. Not a single hive is recorded on this tree in the last few years. There are several other instances of such acts of disappearance in Mumbai and Pune ${ }^{1}$. While there are several reasons for this, scientists believe one of the main contributor is the electromagnetic radiation from mobile phone towers ${ }^{2}$. The World Health Organization (WHO) has acknowledged a short-term effect of this radiation on humans and is researching the longterm effects ${ }^{3}$. It is thus not injudicious to assume that the radiation would pose a risk to bees and other fauna. Considering the growth of mobile phone business in India, this risk is expected to increase over the years. By March 2013, India had an estimated 868 million mobile phone users which are operational through a network of over 500,000 telecom towers (CPCB, 2014). The densely populated Indian cities are riddled with cellular network towers which operate continuously. A recent news report mentioned that 108 mobile phone towers in India exceeded the standard radiation limits ${ }^{4}$. Another threat to the bees is from the extensive use of pesticides in urban parks and gardens. These toxins reach bee larvae through the pollen collection and can kill them (Gutenberg, 2016). One particularly damaging pesticide is neonicotinoid which has sub-lethal effects in bees and a strong evidence linking their use to losses in the bee population (Woodcock, et al., 2016). Other conflicts arise because of exotic tree plantations in parks and on avenues, cutting down of old-growth trees and air and water pollution in the cities. Newly developed suburban areas of Pune like Baner, Pashan and Bawdhan had several bee colonies before the construction frenzy took place. These conflicts are not visible to urban dwellers and until recently, the vanishing urban bee population did not catch media attention. But there has been substantial research and media awareness in the western world, which is evident from United Nations and international magazines carrying the reports. ${ }^{5}$

Another example of a silent human-wildlife conflict is the expulsion of bat colonies from cities. There have been increasing instances of disappearance of bat roosts from Pune and Mumbai ${ }^{6}$. Studies have recorded bat roosting sites in Indian cities. The Indian short-nosed fruit bat Cynopterus sphinx, the Indian flying fox (Pteropus giganteus), the cave dwellers (Hipposideros speoris) and the wrinkle lipped bats (Tadarida plicata), among others, have been noted in Pune city. Over the years, their roosting sites have reduced and their numbers diminished because of several reasons. A major silent conflict which con- fronts the fruit bat population is the changing flora of the city. Plantations are done based on economic and aesthetic considerations and this changes the food availability for bats. An increase in the number of flying foxes is noted in Pune. One reason for this could be the popularity of fruit tree plantations in urban gardens. However, the short-nosed fruit bat population in Pune has reduced because of the silent conflict happening with its habitat. These bats prefer dark and humid ceilings of stone buildings and trees like the Ashoka (Polyalthia longifolia) and Fish-tail palm (Caryota urens). Old Wadas and temples within the old part of Pune city provided such a habitat. They are being replaced by cement buildings and the old growth Ashoka trees are cut down. Old-growth native trees give way to exotic garden varieties. Decorative palms are planted in public gardens, Rain trees (Albizia saman) are popular avenue trees and Glyricidia (Gliricidia sepium) and Eucalyptus (Eucalyptus globulus) (Yardi and Korad, 2001) are planted on hills. These trees are not preferred for roosting by the bats and are therefore equivalent to a habitat loss for them. Large scale habitat loss has had an adverse effect on bat populations. Similar case has been noted in the wrinkle-lipped bats. Their colonies in Nana Wada, an old stone construction public building in Pune, have disappeared because their shelter was removed. The third silent conflict arises from increased vehicular traffic and noise. There were records of bat colonies roosting under bridge arches in Pune, but are no longer there. The heavy traffic and the subsequent increase in oscillations of the bridge may have disturbed them. City noise takes its toll on bird mate finding too. There are cases where bird mating calls are drowned by vehicular noise which hampers breeding. The growing expanse of city areas necessitates electric wires to be laid over long distances. These pose a lethal hazard to large bats, who are often seen electrocuted. All these factors have been detrimental to the bat population in cities.

Mongoose (Herpestes edwardsii) have long been residents of Indian cities and are often seen in residential societies. They have lived in harmony with human beings in cities. In Pune, mongoose were extensively present in the old city areas. The 'wadas' or the old houses and temples had ample space surrounding them, large trees and abundant undergrowth. The mongoose had safe hiding places and a supply of food in the rats that thrived here. They could move safely from one location to another through the small canals and waterways within the city. A pair of mongoose is often sighted in the Mutha river bank near opposite 
Omkareshwar temple in Pune, which is probably one of the last few areas in the city where human interference is minimum. The pair can safely move along the bank in search of food. However, such places are shrinking and in recent years, the mongoose population within the old city has reduced drastically because of large residential structures coming up in place of the wadas. The construction activity of buildings, lasting over a year is highly intrusive for these animals. The completed structures hardly leave any hides and the boundary walls obstruct their passages. The Ambil Odha (canal) which passes through Padmavti has dense thickets along its sides. Mongoose have been using this for movement in search of food. A wall is in the process of being built along the canal, which will cut off the passage movement for the mongoose and other wingless creatures (see picture 1 ). The growing nuisance of stray dogs has affected mongoose too, who are chased by them. On the other hand, there are reports of mongoose population in suburbs like Aundh, Baner and Bawdhan going up. Garbage stacks in open spaces attract hordes of rats. The abundant rat population can support the mongoose, who are seen congregating around the garbage stacks. One large garbage stack in Aundh is reported to have at least four mongooses. The mongoose are harmless to humans and live in harmony, and keep a check on rat populations. But their existence is not even considered when undertaking public works modifications in cities which can potentially interfere with their lives. Urban planners are 'blind' to this conflict as it does not affect humans.

Some of the avian species significantly affected by habitat modification are Barn Owls (Tyto alba) smaller raptors like Shikras (Accipiter badius) and Kestrels (Falco tinnunculus). Barn owls were usually sighted at dusk in the old peth areas of Pune city. As the dense foliage trees reduced in numbers, they have adapted to living on buildings and man-made structures where they are exposed to human contact. Spotted owlets (Athene brama) live in trees and cannot adapt to man-made structures like the barn owls. Their population remains in a few areas in Pune like the Pune university and various college campus, cemeteries, hills and wooded localities like Nav Sahyadri society, Padmavati and the Mula-Mutha sanctuary. Recently three large Gulmohur (Delonix regia) trees were pulled down in S. P. College, in the old city area. These trees were a favorite roost for a pair of spotted owlets. The pair has not been seen since the trees were cut down. Another threat to these raptors is the bright city lights and signage at nights. Such is the brightness that house sparrows have been spotted feeding on a street in Aundh at 2:30 am. This is a significant change in avian behavior. Some years back, the sagacious Indian eagle owl (Bubo bengalensis) was frequently sighted on the Vetal hill, where it had a relatively quiet habitat and ample food. However, the Vetal hill has grown to be one of the most preferred exercise spots in the city. The reticent owl is no longer seen here now. The number of Shikras has diminished in downtown Pune. Here they face hostility from the growing crow population which thrives around human settlements. Crows often mob the raptors and with intimidating behavior. This is a nuisance especially to the barn owls. The reduction in barn owls and shikras shows up in the rising population of three-striped palm squirrel (Funambulus palmarum).

Another case of a silent conflict takes place when open ground in cities is covered with tar, cement or paver blocks. This effectively shuts off the access to soil for various insects like bugs, beetles and ants. Moreover, the impermeable ground cover prevents water puddles from forming and dragonflies and damselflies are deprived of their habitats. Frogs, which were once common in the city, have lost their habitats due to the land covers. Lawns are sprayed with insecticide, which has detrimental effect on insects. The loss of insect diversity, in turn affects the food availability for the insect eating birds and their populations have dwindled. In such urban settings, the avian diversity is being replaced by red whiskered bulbuls (Pycnonotusjocosus), red vented bulbuls (Pycnonotuscafer) and common myna (Acridotheres tristis).

Such silent conflicts occur with many other species,

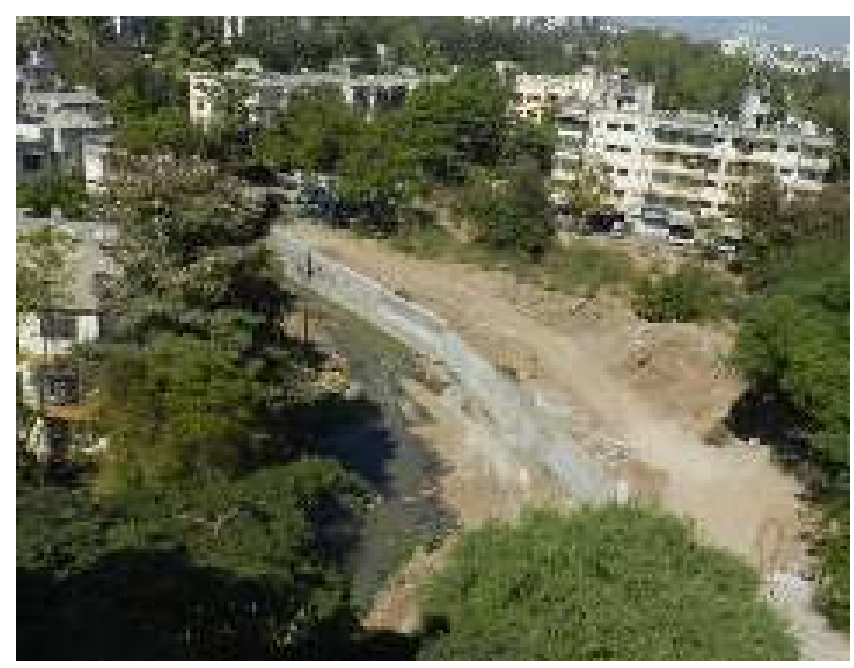

Wall being constructed along Ambil odha 
and are hardly realized. One incident reported from Ambazari lake, Nagpur is about a colony of hundreds of Swifts (species unconfirmed) who resided in a groove between a sloping roof and wall. The old house was pulled down this year and the Swifts are no longer seen here. They are not gregarious birds and in all likelihood, might not have found another suitable nesting site in the neighborhood. Similarly, the increased pollution in Ambazari lake, in the heart of Nagpur, has been a deterrent for the Red crested pochards (Netta rufina) used to come here. The urban predilection for aesthetic trees has killed many a thorny tree like the Babhul (Acacia nilotica). This destroys nesting sites of charismatic nest weaving birds like the Baya. Plantations on grassland habitats, like the Gliricidia (Gliricidia sepium) plantation on Vetal tekdi, has driven away the black naped hares (Lepus nigricollis) which were once seen here. Sewage dumped in the Mutha river has polluted the water to a dark grey colour. Pied kingfishers (Ceryle rudis) which were once recorded here, are unable to fish in this water. Another large scale silent conflict happens when cities spread to adjoining open lands spaces and fill them up with buildings. 'Wastelands' are foraging grounds for several larks, pipits, chats and harriers. They are displaced when open spaces are replaced by buildings. This is evident in the Hinjewadi suburb of Pune, where a large information technology park came up on a wasteland in 1995. Over the last 20 years, the park has extended into three phases covering 680 hectares and another 460 hectares are to be added soon. This is a total loss of habitat for the openland birds ${ }^{7}$.

Another growing menace to urban wildlife is from the nature of urban celebrations. Festivals, weddings, sports victories, political wins and many other occasions are being celebrated with firecrackers, excessively loud music and bright lights. These are frightening for the animals. This author kept a honey bee (Apis cerena indica) colony at home in Pune. On the Laxmi Pujan day of Diwali, the shopkeepers blast firecrackers on the 'muhurat' or auspicious time. The sound and smoke scared off the colony and they swarmed to a safer place.

\section{Violent animal conflicts in urban spaces}

Several fauna pose some form of hazard to humans and this is the source of violent conflict between these species and humans. By far the most discussed cases of violent urban human-wildlife conflicts, in India, involve leopards. The growing leopard population and their dwindling wild food supply pushes them to urban area fringes, which were once their territories. They prowl into residential areas at night and pose a serious threat to humans and domesticated animals. Such cases are encountered in Mumbai suburbs of Borivali where leopards stray away from the Sanjay Gandhi National Park and enter residential complexes. In many cases leopards are beaten to death or are trapped and killed (Figure 2). In 1986 there was a case of a leopard walking into a large industrial premise in Pune. The leopard stayed back in the premises for two days and the factory was shut down and production was lost. Leopard and snake conflicts are some of the most visible forms of urban humanwildlife conflict. As they threaten human life they are extensively covered by media.

The other notable species with whom humans violently engage in conflicts are small Indian civets (Vivvericulaindica), common palm civets (Paradoxurushemaphroditus), langurs (Semnopithecus entellus), macaques (Macaca radiata) and snakes. These animals are purposefully driven away or killed by urban inhabitants. There is a growing nuisance from civets, in the new suburbs of Pune city. Civets have adapted to living around human dwellings and occasionally enter houses in search of easy food. They are known to boldly raid kitchens to eat fruits, leftovers and scraps. Civets are a nuisance in some of the newer residential areas of Bawdhan, Sus and Pashan, where their numbers have increased. In one large residential complex in Bawdhan, the palm civets climb up drainage pipes and raid apartments on the fifth floor. The residents have modified their windows and drain pipes to stop them from entering. Due to their fierce looks and foraging behavior, there have been incidences of civets being stoned or beaten to death. There are incidences of civets running away from human

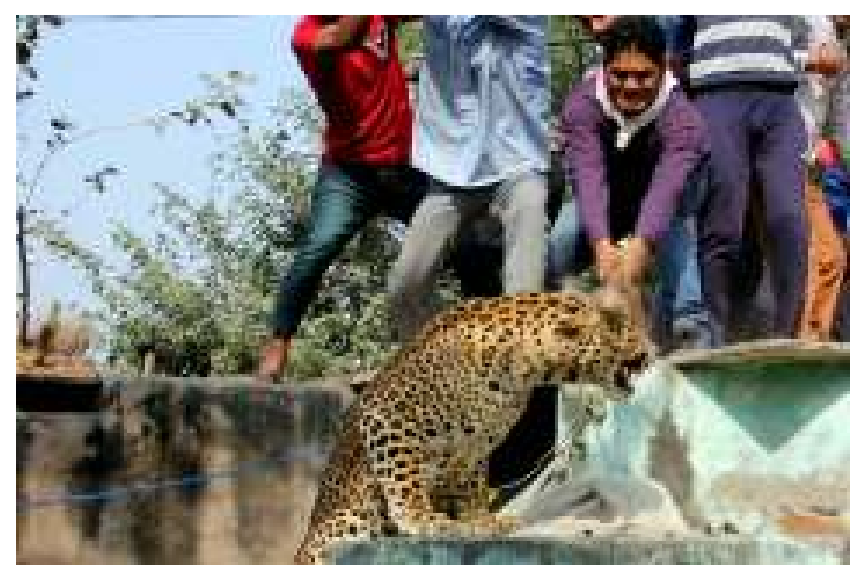

Leopard beaten to death 
wrath have been killed on roads (Figure 3). A similar treatment is meted out to any snake found near human dwellings. In one incident, a snake was caught on a fifth-floor apartment. The society promptly chopped down an old growth Umbar (Ficus racemosa) which was suspected to offer the climbing support to the snake. The tree and the snake were eliminated in the process. In the old parts of Pune city, cobras (Naja naja) have been recorded about 20 years ago. Today, the localities like Nav Sahyadri society, Patil estate, Padmavati, hills and areas near the river banks, have a population of checkered keelbacks (piscator), rat snakes (Ptyas mucosa) and green keelbacks (Macropisthodon plumbicolor). Due to loss of habitat, the snakes enter residential areas and backyards where they are spotted and killed. In many cities, NGOs and individuals are now offering snake rescue services. While there is no documented study, such services can potentially reduce the snake deaths in India. The rescued snakes are either relocated to neighboring woodlands or kept in snake parks. Scientists have expressed concern about the survival rate of the relocated snakes and one study shows deleterious effects on relocated King cobra (Barve, et al., 2013). In the Konkan region of Maharashtra, the red sand boa (Eryx johnii), locally called the 'dutondya' is extensively hunted for its alleged magical powers. This has reduced their population in Konkan. In India, myths and perceptions exist about snakes, which too, is detrimental to their survival. While many organizations are spreading awareness on their conservation, most urban snakes end up facing a gruesome death.

In addition to the silent conflicts discussed earlier bees and bats fall prey to violent conflicts too, a

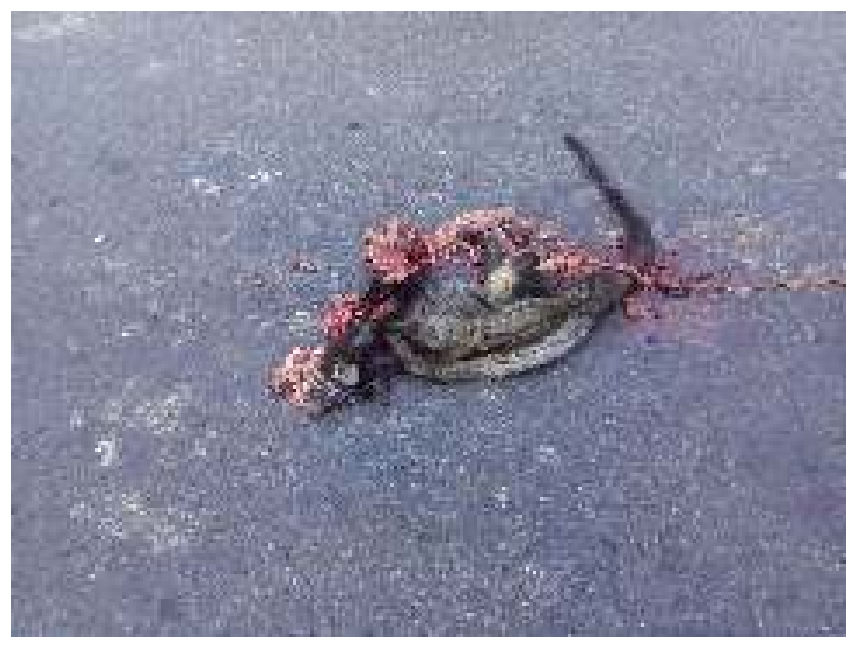

Indian Palm Civet killed on road after being chased away residential colony which has a bee hive, would request its removal by the local administration. The usually docile bees are feared for their stinging bite. In Pune, teams of migrant Adivasis wander the streets in search of bee hives. They climb the trees, drive away the bees and sell off the honey and wax. The author spoke to one team and they boasted of having removed over ten hives in the month. There are instances when residential societies with honey bee colonies have called pest control services for their removal. They spray toxins which kill most of the bees. Such acts will hasten the decline of bees from urban spaces and must be stopped. A similar predicament faces bat colonies. Bats are looked upon as dark and ferocious creatures and considered a nuisance by urban dwellers. They gorge fruits in huge flocks, make an unpleasant noise and spoil the area with their droppings. These perceptions have led them to being driven out. A recent case at the Kalaghoda Museum premises in Colaba, Mumbai, had the staff injecting chemicals in trees to stop their roosting ${ }^{8}$. Like the bees, removal of bat colonies too, is considered to be in human interests.

Monkeys are a menace in urban spaces. As they roam fearlessly in gangs and feed in urban gardens, they are in continuous conflict with humans. Their ability to adapt to new habitats has helped them thrive in dense human settlements. They have learnt to intimidate humans with their fearsome teeth and have turned into pests. In a major incident in 1998, several people were injured as a horde of monkeys stormed into Srinagar and attacked anyone who tried to cross their path. They were driven by hunger and freezing temperatures and raided restaurants, hotels, fruit and tea shops, houses and government offices in search of food. Shrieking menacingly, they barged into an old royal palace and ransacked it and the adjoining state government offices (Sathu, 2017). rural India, some farmers are issued gun licenses and would routinely shoot the gangs; but there is hardly any way of controlling them in cities. In 2007 the wildlife department in Delhi captured over 19000 monkeys and relocated them to Asola Bhatti mines outside Delhi. But the monkeys entered the nearby Sanjay Colony and troubled the residents there. Culling and sterilization are expensive and not easy to implement. As their populations grow, so does the conflict.

The urban airports are another source of violent conflicts in cities. Bird activity is not welcome in this area, lest it interfere with aircraft engines. There are no trees and the grasses are routinely sprayed with 
pesticide to kill insects. Mongoose and civets climb over the wall and intrude are often killed.

\section{Conflict mitigation strategies}

Often, decisions involving wildlife issues in India have been controversial in India. This is mainly due to the differing objectives and values which every stakeholder has. Business communities prioritize economic growth, administration holds social interests important, NGOs fight for animal rights and citizen are unaware or unconcerned. Thus, the success of the conflict mitigation program depends largely on the ability of the decision makers to identify stakeholders and incorporate their values and objectives in the policy making process (Messmer, 2009). Guynn (1997) makes a list of elements of a successful conflict management process. These are (1) clearly defined objectives (2) clearly defined authority levels (3) participant agreement (4) inclusion of team building exercise (5) maintenance of continuity by not allowing substitutes (6) implementation of guidelines and activities that promote violent listening (7) achievement of success with smaller issues before addressing larger concerns. The author suggests adding one more point to this list - making stakeholders aware of each other's problems and objectives. This is important for a country like India, where an estimated $74 \%$ population ${ }^{9}$ is illiterate and perhaps unaware of the multiple problems arising from human-wildlife conflicts.

Clearly, the resolution of both types of conflicts discussed here require separate approaches towards mitigation. In silent conflicts, the bottom line is the non-awareness of the problem in the perpetrators. Moreover, many of these conflicts are not easily observed and hence go unreported in media. Thus, even well-intentioned individuals or organizations may not get a chance to avoid their actions. The first step suggested towards reducing silent conflicts is increasing social awareness. While NGOs and other organizations have successfully created awareness campaigns in India, this can be driven by local and state governments as a means of preserving the local faunal peculiarities of the city. One such campaign is recently launched by the government of Nagaland ${ }^{10}$. The locals have lived off hunting but the alarming decrease in species diversity and reduction in populations of some keystone species has prompted the government to take up the awareness campaign. The government of Maharashtra has an ongoing awareness program on the leopard-human conflict ${ }^{11}$, but that is a visible conflict. There is no similar example yet on the silent ones. The Royal Society for Protection of Birds (RSPB) has undertaken successful awareness campaigns in the past while in India the BNHS has been working on an Urban Biodiversity and Ecorestoration program in Mumbai. Increasing social awareness is challenging, but not impossible. Analytical and communication skills are essential in the mitigation of such conflicts. Use of social networking, digital media and innovatively conveying the message are important elements for its success. The next step is identifying key target groups which are involved in these conflicts and spreading awareness among them. Architects, builders, local government departments and corporate houses are some of the groups.

On the other hand, the 'violent conflicts' need a stakeholder approach. The diversity in stakeholders can complicate the situation. For example, in handling incidences of leopard intrusion, citizen, local government, wildlife department and NGOs working in nature protection could be the potential stakeholders. Each one could have a differing perception of the intruder and hence differing views on how to handle the situation. Handling violent conflicts is thus dependent on managing stakeholder differences, prioritizing the issues and negotiating the solution. The skills required here are different from the ones needed for silent conflict management. Moreover, there are tried and tested ways to overcome these conflicts. Some are successful while others delay the impact of the problem. Some of the popular one are - relocation (snakes, leopards, bees), protection in enclosures within the city (leopards), sterilization to reduce populations (monkeys, dogs), offering compensation to move out (usually used in threatened fauna habitats), killing (dogs, pigs, bats) and use of noise deterrents (monkeys). It is evident that some measures are anthropocentric, but humans have created conditions suitable for their growth and a control on their populations is imperative in many cases. Economic, social and personal benefits must be considered in mitigation of violent conflicts.

\section{Conclusions}

Urban wildlife in India is under severe pressure from the proliferation of human activities. Even though some species are a threat to life or human activities, many others die or move out unnoticed. If the biodiversity of the cities needs to be conserved and improved, it is crucial to increase the social awareness and take hard steps to mitigate the situation. The Indian Constitution and the government's commitment to the Sustainable Development Goals 
makes it mandatory to preserve and protect all forms of life in the country. Indians have largely lived in a harmonious relationship with nature. It is of critical importance that we reconsider our priorities and bestow the same importance to nature as our forefathers once did.

\section{References}

Barve, S., Bhaisare, D., Giri, A., Shankar, P., Whittaker, R., and Goode, M. (2013). A preliminary study on translocation of "rescued" King Cobras (Ophiophagus hannah). Hamadryad, 36(2), 80-86.

Boyle, K. J., and Bishop, R. C. (1987). Valuing wildlife in benefit-cost analyses: A case study involving endangered species. Water Resources Research, 23(5), 943-950.

Brahme, N. (2002). Times of India. Retrieved from Conservation experts bat for bird, flora database of Mula and Mutha: http:// epaper.timesofindia.com/Default/Layout/Inc $1 \mathrm{ud} \mathrm{e} \mathrm{s} \mathrm{/} \mathrm{M} \mathrm{I} \mathrm{R} \mathrm{R} \mathrm{O} \mathrm{R} \mathrm{E} \mathrm{W} \mathrm{/} \mathrm{A} \mathrm{r} \mathrm{t}$ Win.asp?From $=$ Archive $\&$ Source $=$ Page $\& S k i n=$ MIRRORNEW\&BaseHref=PMIR\%2F2010\%2F09\% 2F20\&GZ=T\&View Mode $=$ HTML\&EntityId $=$ Ar00100\&AppName $=1$

Callicott, J. (2003). The philosophical value of wildliife. In S. Armstrong, and R. Botzler, The Animal Ethics Reader (pp. 383-386). New York: Routledge.

CPCB. (2014). Awareness note on mobile tower radiation and its impact on environment. Central Pollution Control Board of India. New Delhi: CPCB. Retrieved from http://cpcb.nic.in/Note_Mobile_ Tower_Radiation_UPCD_Div.pdf

D.J. Rapport, R. C. (1998). Assessing ecosystem health. Tree, 13(10), 397-402.

Dearborn, D. C., and Kark, S. (2009). Motivations for Conserving Urban Biodiversity. Conservation Biology, 1-9. doi:10.1111/j.1523-1739.2009.01328.x

Grimm, N. B., Faeth, S. H., Golubiewski, N. E., Redman, C. L., Wu, J., Bai, X., and Briggs, J. M. (2008). Global Change and the Ecology of Cities. Science, 319(5864), 756-760.

Gutenberg, J. (2016, June 24). Neonicotinoid pesticides cause harm to honeybees. Retrieved from Science Daily : https://www.sciencedaily.com/releases / 2016/06/160624135849.htm

Guynn, D. (1997). Miracle in Montana: managing conflicts over private lands and public wildlife issues. Transactions of the North American Wildlife and Natural Resource Conference, 62, pp. 146-154.

Kuhn, I. R. (2004). The flora of German cities is naturally species rich. Evolutionary Ecology Research,
6, 749-764.

Lowry, H., Lill, A., and Wong, B. B. (2012). Behavioural responses of wildlife to urban environments. Biological Reviews, 000-000. doi:10.1111/ brv.12012

McKinney, M. L. (2008). Effects of urbanization on species richness: A review of plants and animals. Urban Ecosystems, 11(2), 161-176. doi:10.1007/ s11252-007-0045-4

McKinsey. (2011). Urban world: Mapping the econmic power of cities. McKinsey.

Messmer, T. A. (2009). Human-wildlife confl icts: emerging challenges and opportunities. HumanWildlife Conflicts, 3(1), 10-17.

Ministry of Home Affairs. (2011, January 2). Provisional Population Totals. Retrieved from Census India : http:/ / censusindia.gov.in/2011-provresults / paper2/data_files/India2/1.\%20Data\% 20Highlight.pdf

Mohan, R., and Dasgupta, S. (2004). Urban Development in India in the 21st Century: Policies for Accelerating Urban Growth. Fifth Annual Conference on Indian Economic Policy Reform at. Stanford: Stanford Centre for International Development.

Nalavde, S. B. (2006). Retreating wild mammals of Pune Urban Area. Retrieved from Ranwa: http:/ / www.ranwa.org/punealive/pamam.htm

Necessity of a second home for the Asiatic Lion, 337 OF 1995 (Supreme Court of india 1995).

NWRC. (2010). Reducing Urban Wildlife conflicts. Retrieved from US Department of Agriculture: https:/ / www.aphis.usda.gov/wildlife_damage/ nwrc/publications/factsheets/FS_urban_wildlife _conflicts.pdf

Planning Commission. (2007). Eleventh Five-year Plan. Retrieved from Planning Commission: http:/ /www.planningcommission.nic.in/plans/planrel/ fiveyr/11th/11_v1/11th_vol1.pdf

Rudel, T. K., Coomes, O. T., Moran, E., Achard, F., Angelsen, A., Xu, J., and Lambin, E. (2005). Forest transitions: towards a global understanding of land use change. Global Environmental Change, 15, 2331.

Saldiva, P., and Bohm, G. (1998). Animal Indicators of Adverse Effects Associated with Air Pollution. Ecosystem Health, 4(4), 230-235.

Sathu, J. (2017, January 3). Electronic Telegraph Report. Retrieved from Facts and details: http:/ / facts anddetails.com/asian/cat68/sub430/item2484 .html

Seto, K. C., Güneralp, B., and Hutyra, L. R. (2012). 
Global forecasts of urban expansion to 2030 and direct impacts on biodiversity and carbon pools. In B. L. Turner (Ed.), Proceedings of the National Academy of Sciences of the United States of America, 109, pp. 16083-16088. Retrieved January 12, 2017, from http://www.pnas.org/content/109 /40/16083.long

SPG Marine Ecology Centre. (2006). Godrej. Retrieved from Mangroves in Mumbai: http://www. mangroves.godrej.com/MangrovesinMumbai.htm

Valiela, I., Bowen, J. L., and York, J. K. (2001). Mangrove Forests : One of the World's Threatened Major Tropical Environments. BioScience, 51(10). doi: https://doi.org/10.1641/0006-3568(2001)051[0807: MFOOTW]2.0.CO;2

Woodcock, B. A., Isaac, N. J., Bullock, J. M., Roy, D. B., Garthwaite, D. G., Crowe, A., and Pywell, R. F. (2016). Impacts of neonicotinoid use on long-term population changes in wild bees in England. Nature. doi:10.1038/ncomms12459

WWF. (2005, January 3). Human Wildlife conflict manual: Wildlife Management Series. Retrieved from Panda.org: http://wwf.panda.org/index.cfm ?uNewsID $=88920$

Yardi, K., and Korad, V. (2001). Bat Fauna of Pune city. Journal of Ecological Society, 13/14(1), 71-73.

\section{Endnotes}

1. http://timesofindia.indiatimes.com/india/ Honey-where-are-the-bees / articleshow / $\begin{array}{lllllllllll}5 & 1 & 5 & 6 & 4 & 2 & 3 & . & \mathrm{c} & \mathrm{m} & \mathrm{s}\end{array}$ http://punemirror.indiatimes.com/pune/others/Honeybees-dying-due-to-pesticides / a m p_articleshow/44126329.cms http://mumbaimirror.indiatimes.com/mumbai/ other /City-losing-its-buzz/amp_articleshow / 16023124.cms

2. http://www.telegraph.co.uk/news/earth/wildlife/7778401/Mobile-phones-responsible-for-disappearance-of-honey-bee.html

3. http://www.who.int/mediacentre/factsheets/ fs193/en/

4. http://www.huffingtonpost.in/2016/08/10/ mobile-phone-towers-radiation/

5. http://www.newsweek.com/bee-populationsvanish-usda-tries-keep-them-fed-230271 http: / / www.un.org / apps / new s / story.asp?NewsID=37731\#.WHMmwn39Vw9

6. http://timesofindia.indiatimes.com/city/pune/ Drop-in-Western-Ghats-bat-species-Study / a r t i c le s h ow / 34987512 . c m s http://www.dnaindia.com/india/reportmumbai-bat-lovers-join-forces-to-save-theirleathery-little-friends-2013336

7. http://www.thehindubusinessline.com/todayspaper/tp-info-tech/hinjewadi-phase-iii-set-toget-sez-status/article2196581.ece

8. http://www.dnaindia.com/india/report$\begin{array}{llllll}m & u & m & b & a & i\end{array}$ -bat-lovers-join-forces-to-save-their-leatherylittle-friends-2013336

9. http://timesofindia.indiatimes.com/india/Literacy-rate-up-but-so-is-illiteracy / articleshow / 50749744.cms

10. https://ipr.nagaland.gov.in/NagaNews?ID= HUMAN\%20ANIMAL \% 20CONFLICT\%20 MITIGATION\%20AWARENESS\%20CAMPAIGN $\% 200 N \% 204$ th $\% 20$ NOVEMBER

11. http://www.mumbaikarsforsgnp.com/docs/ leopard_awareness_camp_report_SGNP.pdf 